\title{
Customer Lifetime Value Analysis to Profitability Management: A framework to strategic marketing
}

\author{
Mohammad Safari ${ }^{*}$ \\ Faculty of Management, University of Tehran, Iran \\ *E-mail address: m.safari@ut.ac.ir
}

\section{ABSTRACT}

The more a marketing paradigm evolves, the more long-term rel its importance. Nowadays most of corporations and firms in the wo 4, includin servicers, increasingly gain their incomes and profits through con iru and mair ining long-term relationship with customers. The move towards a customer-cent ed ap ch to marketing, coupled with the increasing availability of customer transaction da , How led to a and estimating customer lifetime value (CLV). Further hore as marketing endeavours to be more accountable, the need of tools and models for measurin and evaluatirg efforts and investments that accomplish in marketing extent, is felt. This research med to present a framework to analysis customer lifetime value in order to strategic marketing prac

Keywords: customer lifetime value; customer pro tabry anagement; strategic marketing

\section{INTRODUCTION}

The more a mang para $/$ evolves, the more long-term relationship with customers gains its mpo ce. CRI 1 , a recent marketing paradigm, pursues long-term relationship witb prefitable cu mers. It can be a starting point of relationship management to understand and $n$ asure the rue value of customers since marketing management as a whole is to tep syed ward the targeted customers and profitable customers, to foster customers' full fit pot ntial. Corporate success depends on an organization's ability to build anc intain and valued customer relationships. Therefore, it is essential to build ref st ategies for customers based on their value. (Kim et al, 2006). Customer Rela ar agement (CRM) has become a leading business strategy in highly compet business environment. CRM can be viewed as 'Managerial efforts to manage business in actions with customers by combining business processes and technologies that seek to understand a company's customers' (Kim, Suh, \& Hwang, 2003). Companies are becoming increasingly aware of the many potential benefits provided by CRM. Some potential benefits of CRM are as follows: (1) Increased customer retention and loyalty, (2) Higher customer profitability, (3) Creation value for the customer, (4) Customization of products and services, (5) Lower process, higher quality products and services (Jutla, Craig, \& Bodorik, 2001). When evaluating customer profitability, marketers are often reminded of the $80 / 20$ rule $(80 \%$ of the profits are produced by top $20 \%$ of profitable customers and $80 \%$ of the costs are produced by top 20\% of unprofitable customers) (Duboff, 1992). 
The core parts of CRM activities are understanding customers' profitability and retain profitable customers (Hawkes, 2000). To cultivate the full profit potentials of customers, many companies already try to measure and use customer value in their management activities (Gloy, Akridge, \& Preckel, 1997; Rosset, Neumann, Eick, Vatnik, \& Idan, 2002). Therefore, many firms are needed to assess their customers' value and build strategies to retain profitable customers.

Therefore, over the past decade, Customer Relationship Management (CRM) has become a leading strategy in highly competitive business environments. Companies increasingly derive revenue from the creation and enhancement of long-term relatinnships with their customers (Coussement \& Van den Poel, 2008). This move toward a cus ar centric approach to marketing, coupled with the increasing availability $f$ custom transaction data, has led to an interest in estimating and understanding Custo Lifetir Value (CLV). CLV is viewed as the present value of the future cash flo ws associa wit a customer (Pfeifer et al, 2005). By understanding the CLV of individy custor rs ena os the decision maker to improve the customer segmentation and mar etr. source llocation efforts (Kim and Lee, 2007; Kumar et al, 2006) and this in tur will leac high cr retention rates and profits for the firm (Hawkes, 2000).

\section{CUSTOMER RELATIONSHIP MANAGEMF NT}

Most organizations have perceived the cus relati hship management (CRM) concept as a technological solution for problems in in areas, accompanied by a great deal of uncoordinated initiatives. Neverthele $\mathrm{M}$ must be conceived as a strategy, due to its human, technological, and processes imp caty the time an organization decides to implement it (Mendoza et al, 2006)-Within t present business environment, characterized by an increasingly aggressive co npe ce, the attle to win customers is stronger every day. Companies that enter to comp in a ew mark $\mu$ weaken the already existing and solid ones, due to the new ways of do an me trum. businesses. One of the factors that have driven all these changes is the onstant c oe and the evolution of technology. Because of this reality, the CRM cor ep evolved n such a way that nowadays it must be viewed as a strategy to maintai a long-to relationship with the customers (Mendoza et al, 2006).

In the la $1960 \mathrm{~s}$, Levil aggested that the goal of businesses was to "create and maintain cu mers" Fox and Stead, 2000). After more than two generations, it can be appreciated ho e CRM concept, and the need to maintain a long-term relationship with custom is bed ing a important issue. The main reason for this customer's importance rety a with the con any is the change in the way of doing business nowadays (Goldenberg, 260 In regard the subject, the companies have a new trend to implement CRM as a factor that will allow the $y$ survive in these new market conditions, favouring the relationship with their customers Mendoza et al, 2006).

To achieve the CRM objective, there is a series of aspects involved (Chen and Popvich, 2003; Mendoza et al, 2006):

- The Processes through which the customer relates with the organization, according to Thompson, are: marketing, sales, and service [18]. In addition to these processes, and depending on the area of business, there are other processes which are directly affected and that must also be considered. The latter processes, however, are the most common and, generally, of broader scope. 
- The Human factor (people) with a key role within the CRM strategy, both on behalf of employees within the organization (who must be immersed in a cultural change) as of the customers.

- The Technology is what facilitates implementing the CRM strategy; thus, it is necessary to know which of these technologies are and how they favour the CRM strategy.

Many businesses today realise the importance of CRM and its potential to help them achieve and sustain a competitive edge. These organizations are already changing their business processes and building technology solutions that enable them to acquire new customers, retain existing ones, and maximise their lifetime value.

Although CRM is a recent concept, its tenets have been around for some Marketers have always promoted close relationships with customers. Custor profitabil has been touted as significant for many years, but has been difficult to $c^{\text {h }}$ term as ma institutions are organised along product or channel lines as opposed to custamer. ila 1y, the concept of mass customisation has been in the literature for near deca (Pine, 993). However, all have remained essentially theoretical concepts; aspir ons er than practical or commercial reality. Today, due to advances in infor ation an com nunications technology, the promise of one-to-one relationships, cus on value an sis and mass customisation are now possible. Yet, despite the role of nolo hese manifestations are less of a technological phenomenon than a profound crang in the ey Mics of information
(Peppard, 2000).

Central to the idea of CRM is the assumptio that custom/rs differ in their needs and the value they generate for the firm, and that the w. vustomer are managed should reflect these differences. CRM is therefore not abo toffering ngle customer the best possible service, but about treating customers differ thending on their CLV Such appropriate treatment can have many faces, starting wit of en loyalty programs to retain the most profitable customers (Shugan, 200-through o the abandonment of unprofitable customer relationships (Haenlein et al., 20,6).

Intuitive appeal: Becaus the w it alloys companies to know exactly how much each customer is worth in rupe moms, dincruore, exactly how much a marketing department should be willing to spe to acquiro chycustomer. In reality, however, it is often difficult to make such calculatio is a to the col plexity of the calculations and lack of reliable input data, or both.

Calculati of of $C L V$ : dep as on the nature of the customer relationship for example; Companies a r a retail banks can count on a reasonably reliable stream ecurring evenue from each customer.

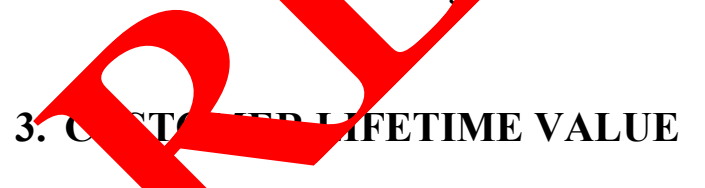

Cus or Lifetime Value has been studied under the name of LTV, Customer Value, Customer Equity and Customer Profitability. The concept is defined as the sum of the revenues gained from company's customers over the lifetime of transactions after deduction of the total cost of attracting, selling and servicing customers, taking into account the time value of money (Hwang et al, 2004; Safari, 2012). The basic formula for calculating CLV for customer $i$ at time $t$ for a finite time horizon $T$ (Berger \& Nasr, 2004) is: 


$$
C L V_{i, t}=\sum_{t=0}^{T} \frac{\text { profit }_{i, t}}{(1+d)^{t}} \quad, \quad C L V_{i}=\sum_{t=1}^{T} \frac{\text { Revenue }_{i, t}}{(1+d)^{t}}-\sum_{i=1}^{T} \frac{\text { Cost }_{i, t}}{(1+d)^{t}}
$$

Where $d$ is a pre-determined discount rate. In multi-service industries, Profit ${ }_{i, t}$ is defined as:

$$
\operatorname{profit}_{i, t}=\sum_{j=1}^{j} \operatorname{Serv}_{i j, t} * \operatorname{Usage}_{i j, t} * M \arg \operatorname{in}_{i j, t}
$$

Here $J$ is the number of different services sold, $\operatorname{Serv}_{i j, t}$ is a dummy indio $\mathrm{g}$ wheth customer $i$ purchases service $j$ at time $t$, Usage $i j, t$ is the amount of that se vive pu sed a d Margin $_{\mathrm{ij}, t}$ is the average profit margin for service $j$ (Beniot and Poel, 20 9).

Also, CLV may consist the following relations:

In this formula assumed that the marginal val of the customers at period $\mathrm{t}$ is $m_{t}$, the discount rate is $i$, the customer retention rate is $r(r$ not be a f xed value, but vary within a range. Here, we make it fixed to simplify the model). discounted cash flow value is the single equa contribution to the corporate value.

Where e follo ing is truc:

$$
C L V=\sum_{t=0}^{\infty} m_{t} \frac{r^{t}}{(1+i)^{\prime}}
$$


Theoretically, CLV models should estimate the value of a customer over the entire customer's lifetime. However, in practice most researchers use a finite time horizon of three or four years (Donkers et al, 2007; Rust et al, 2000, Beniot and Poel, 2009). Three to four years is a good estimate for the horizon over which the current business environment would not substantially change and even then, there is significant uncertainty in predicting customer behaviour (Venkatesan et al, 2007). Moreover, some research considers an even shorter time horizon (Hwang et al, 2004).

CLV has been analyzed in a substantial number of different domains, varying from econometric models to computer science techniques. However, the key questions aremally very similar: "What are the drivers of CLV?", "Which customers are the future y ost var Ye ones?", "How to address the top customers?", etc. Several authors give an rview of variety of modeling procedures that were used in search for answers to the $k$ questio (Berger and Nasr, 1998; Donkers et al, 2007; Gupta et al, 2006; Ngai Xiu \& C. 20,8 ; Venkatesan and Kumar, 2004). In general, one can distinguish two br d clas of mo cls in the current contractual setting. First, a large group of models focus on hoices ystomers face when buying an additional service or product. A customer' ifetime is seen as the sum of the distinct contributions per service or prody ch his appro is appealing because of the natural way in which the CLV prediction is bu up. In a first stage, an estimation is made on the probability of a customer bym a given duct or service. The second stage is then to combine these probabilitie with the margi s associated with the product or service into an aggregate prediction of a ustomer's lifetime value. This approach also has the advantage of providing more insight in the factos that drive customer value. The main drawbacks are the amount of madeling requ the often poorer predictions. Examples of this approach are found in $\quad$ and Kumar (2004) and Hwang et al. (2004). The second large group of models do $\mathrm{n} / \mathrm{N}$ the two stage method, but focuses directly on relationship length and tatal profit since the individual-level choice modeling is left aside, the process of pros acin CLV e imates is much more straightforward and prediction accuracy is highen rho \& Don ers, 2001). As such, this approach turns the disadvantages of the first a factors that drive consy er profita $v$ is limited compared to the choice-based approach. Examples of CLV re aro llowing s direct approach are found in Malthouse \& Blattberg (2005) and in Han and tales (2002).

Given the one of the ke) sues when decision makers use the CLV metric is whether the firm cap rovide adequate prediction of the CLV of each customer in the database (Malthouse \& iberg, 05; Venkatesan \& Kumar, 2004), it is clear that the predictive accura the $\mathrm{V}$ is of primordial importance. Furthermore, these predictions are often user $^{\prime}$ as gu elines to avestments in segments of customers (Zeithaml et al, 2001; Beniot and Poc

n evaluating customer profitability, marketers are often reminded of the 80/20 rule ( $80 \%$ of $\mathrm{ofits}$ are produced by top $20 \%$ of profitable customers and $80 \%$ of the costs are produced by top $20 \%$ of unprofitable customers) (Duboff, 1992; Gloy et al, 1997). This finding has important implications for both the two-stage approach as well as for the approach that models CLV directly. For researchers using the two-step CLV approach, the problem arises when modeling the choice problem. Since the largest group of customers buys no or only a very limited amount of products or services and only a small group of customers buys many products or services, the researcher should be aware of the fact that he or she is modeling rare events. In this rare-event situation, it is known that parametric choice models easily break down (Gupta et al, 2006; Beniot and Poel, 2009). The other approach, where the 
researcher focuses directly on the relationship length and total profits, leaves aside the individual-level choice modeling step. However, the problem of rare events cannot be totally avoided. This is because the underlying process (the 80/20 rule) results in a lifetime value variable that tends to have a strong non-normal distribution and the usual assumption of homoscedasticity is hard to maintain (Fader et al, 2005; Malthouse \& Blattberg, 2005; Beniot and Poel, 2009).

\section{CLV REQUIREMENTS}

Data inputs commonly used when making customer lifetime value calcul ons are: Acquisition cost - Churn rate - Discount rate - Retention cost - Tin Revenue - Profit Margin (Safari et al, 2014).

- Acquisition cost: The amount of money a marketing department $b$ to $\mathrm{sp}$, on a crage, to acquire a single new customer.

- Churn rate: The percentage of customers who end their rel ionship a company in a given time period. Churn rate typically applies to sub och on servicy such as long distance phone service or magazines.

- Discount rate: the cost of capital used to disc unt rature rev from a customer. Discounting is an advanced topic that is frequ htly ignored in castomer lifetime value calculations. The current interest rate is sometir s used as a limple (but incorrect) proxy for discount rate.

- Retention cost: The amount of money company spend in a given time period to retain an existing customer. Retent include customer support, billing, promotional incentives, etc.

- Time period: The unit of time which customer relationship is divided for analysis. A year is the most commor y use time per d. Customer lifetime value is a multi period calculation, usually streten point is viewed as tog spocula to be reliable.

- Periodic Revenue amount o énue collected from a customer in the time period.

- Profit Margin: ofit a percentage of revenue. Depending on circumstances this may be reflected a percent. of gross or net profit. For incremental marketing that does not incur any in remental verhead that would be allocated against profit, gross profit margino acc-ptabl

\section{USTC MER PR JFITABILITY MANAGEMENT}

C. mer profitability management (CPM) is a continuous process to trace and develop a respons path for obtaining values from customers, as well as creating values for customers, according to changes in industrial conditions. A clear path can guide a firm to make right strategic choices in determining desired marketing outcomes and allocating limited resources to marketing initiatives. Making strategic choices in response to socioeconomic changes from among many possible marketing initiatives is a difficult, yet crucial task for firms. However, an important principle of strategic choice is to select marketing initiatives that can actually rise existing or create new value for customers. Some firms forget this principle and wind up trapped in destructive price wars. 
Although price reductions may temporarily attract customers, it fails in CPM because products or services without improvements and differentiation cannot retain profitable customers in the long run. Moreover, the purpose of a responsive path is to respond to unpredictable customer behaviour. Although a customer database might allow a firm to trace changes in the profitability of a given customer, strategies derived from data analysis are often too passive to respond to the rapid changes in the market. This study proposes an alternative approach which effectively monitors shifts in customer profitability to help a firm win back defecting customers, detect potential customers, and evaluate the performance of upgrading customers. Such an approach takes a holistic view of a firm's marketing efforts, in which the strategic, tactical and operational efficiencies of Customer Profitability Manag inent, a $\mathrm{g}$ with efficient management of tangible and intangible assets allow firms to con ally ident value-creating opportunities for increasing customer profitability (Wang nd g, 2006 Indeed, based on calculated CLV, and determining the profitable and w profitable tom crs to the firm/organization, it is more useful to segment the customers d the inplen at the most effective strategies for each of the segment of customers in th ma

\section{PROPOSED RESEARCH FRAMEWORK}

In this section the proposed research framew rk has been pres nted. This conceptual framework is a new approach in customer segmenta on context. More Customer Profitability Management based on segmented customer sections 11 explain In the figure 1, the research conceptual framework has been presented. This fram cermines both of steps of this paper and important parameters of the final 1

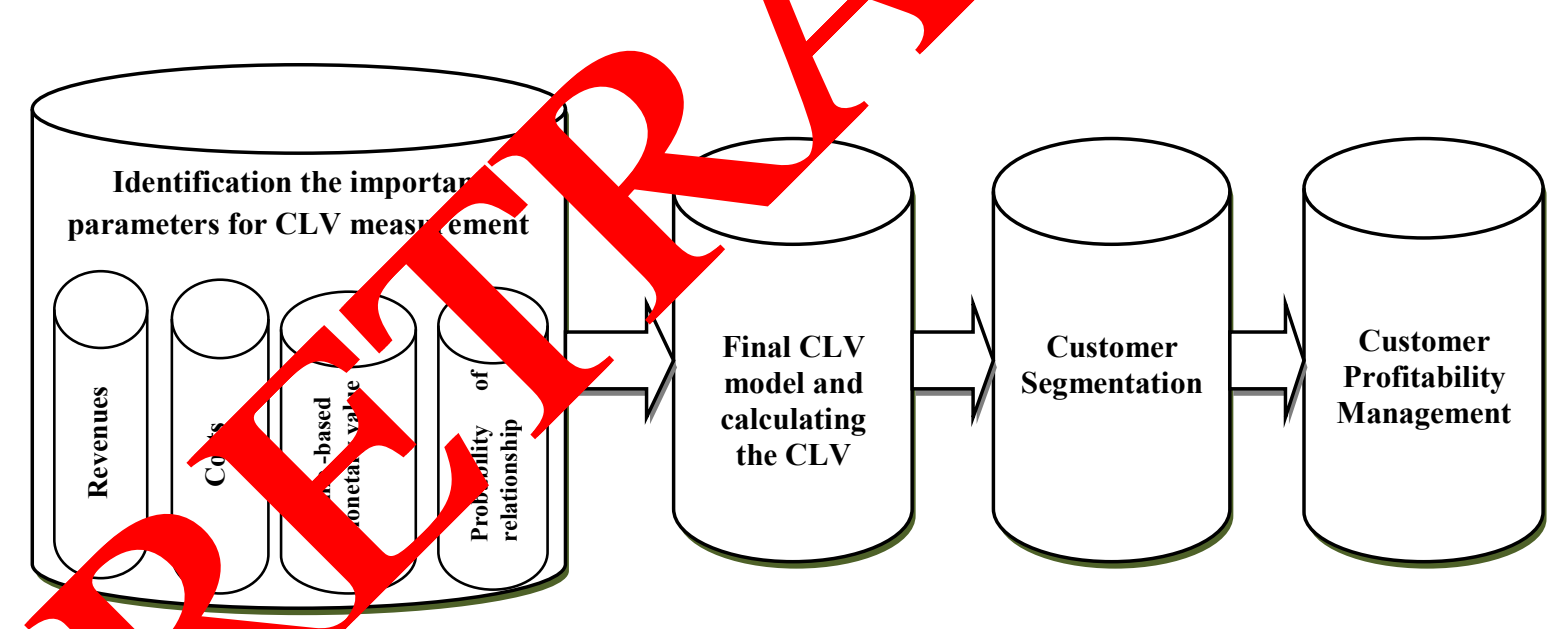

Figure 1. Research conceptual Framework.

\section{CONCLUSION}

Customer value has been studied under the name of LTV (Life Time Value), CLV (Customer Lifetime Value), CE (Customer Equity) and Customer Profitability. The previous researches define LTV as the sum of the revenues gained from company's customers over the lifetime of transactions after the deduction of the total cost of attracting, selling, and servicing customers, taking into account the time value of money (Dwyer, 1997; Hoekstra \& Huizingh, 
1999; Jain \& Singh, 2002; Kim et al, 2006). Customer segmentation methods using LTV can be classified into three categories: (1) segmentation by using only LTV values, (2) segmentation by using LTV components and (3) segmentation by considering both LTV values and other information. The main purpose of this research was to present a conceptual framework towards managing the CLV that was applicable for strategic marketing practices especially in the new turbulent world business. For the top and golden customers the satisfaction and loyalty programs are necessary. For this purpose the related researches for maintaining customers and also enhanced the lifetime value may be implemented. Innovative plans such as following is necessary for top customer's retention and enhance their wo for the retail bank:

- Services customization best related to the real customer's needs and wants

- Building the Customer Club

- Using the Discount Program just related to the top customers

- Up- Selling programs

- Cross- Selling programs

- Providing the innovative and up-to-date services

- Continues relationship with customers and using the ery plicable eld studies for customer's satisfaction and loyalty and then complaiv thanding ton time.

\section{References}

[1] Aghaei, M.; Vahedi, E.; Safari-Kahr ${ }^{-1}$ M. \& Ph (2014). An Examination of the Relationship between Services M Mix and Brand Equity Dimensions. Procedia-Social and Behavioral Scien es. us, 5-869.

[2] Aghaie, M.; Vahedi, E.; As '1ahi, A. Safari-Kahreh, M. (2014). An empirical Investigating to Effects $c$ serv es Mark ing mix on Brand Dimensions in Order to enhance brand Equity To Ton's Chain Stores. Research Journal of Recent Sciences, 3 (2), 43

[3] Beniot, Dries F den Poel 2 . (2009). Benefits of Quantile Regression for the Analysis of $C$ stom ifetime value in a Contractual Setting: An Application in Financial vices. Ex, Systems with Applications. 6, 10475-10484.

[4] Berger P., \& Tasr, N. (1 98). Customer lifetime value: marketing models and appko ns Journ of Interactive Marketing, 12 (1), 49-61.

[5] Chan, I. Vvich K. (2003). Understanding customer relationship management (c) 1). Peo ${ }_{1}$ process, and technology, Business Process Management Journal, 9

(5) $372-688$

[6] ussement, K. \& Van den Poel, D. (2008). Churn prediction in subscription services: A aplication of support vector machines while comparing two parameter-selection tech iques. Expert Systems with applications, 34 (1), 313-327.

[7] Donkers, B., Verhoef, P. \& de Jong, M. (2007). Modeling CLV: a test of competing models in the insurance industry. Quantitative Marketing and Economics, 5(2), 163190.

[8] Duboff, R. S. (1992). Marketing to maximize profitability. The Journal of Business Strategy, 13(6), 10-13. 
[9] Fathollahzadeh, M.; Hashemi, A. \& Safari-Kahreh, M. (2011). Designing a New Model for Determining Customer Value Satisfaction and Loyalty towards Banking Sector of Iran. European Journal of Economics, Finance and Administrative Sciences, 28, 126-138.

[10] Gloy, B. A., Akridge, J. T., \& Preckel, P. V. (1997). Customer lifetime value: An application in the rural petroleum market. Agribusiness, 13(3), 335-347.

[11] Gupta, S., Hanssens, D., Hardie, B., Kahn, W., Kumar, V., Lin, N. \& Sriram, N.R.S (2006). Modeling customer lifetime value. Journal of Service Research, 9(2), 139-155.

[12] Haenlein, Michael, Kaplan, Andreas M. and Schoder, Detlef. (2006). Valu option of abandoning unprofitable customers when calculating customer fetime value. Journal of Marketing, 70 (3), 5-20.

[13] Hwang, H., Jung, T. \& Suh, E. (2004). An LTV model and custom Acgma tion based on customer value: a case study on the wireless telecomm nicat $\mathrm{n}$ indi Expert Systems with Applications, 26(2), 181-188.

[14] Jain, D., \& Singh, S. S. (2002). Customer lifetime value r search in arketi g: A review and future directions. Journal of Interactive $M g$ ing, 16(2),

[15] Kamalabadi, N.; Bayat, A.; Ahmadi, P. \& Safari-Ka eh, M 2008). Presentation a new algorithm for performance measurement of chain wsing FMADM Approach. World Applied Sciences Journal, 5 ,5), 582-589.

[16] Kim, E. \& Lee, B. (2007). An economic anal is of custoner selection and leverage strategies in a market where network externa s exist. Decision Support Systems, 44(1), 124-134.

[17] Kim, J., Suh, E., \& Hwang, H. (2003) an for evaluating the effectiveness of CRM using the balanced scorecard. Jo rn $/{ }^{\prime}$, eractive Marketing, 17(2), 5-19.

[18] Kim, S., Jung, T., Suh, E., g, H. (2 06). Customer segmentation and strategy development based on c stome lifetime tue: A case study. Expert Systems with Applications, 31, 101

[19] Kumar, V., Lemo , K.\& Pa uraman, A. (2006). Managing customers for value: An overview and $\mathrm{r} \%$ h agenda. Irnal of Service Research, 9(2), 87-94.

[20] Malthouse,E. \& b berg, R.C (2005). Can we predict customer lifetime value? Journal o Ameractive N loting, 19(1), 2-16.

[21] Mend a, Lu - .; Mariıs, Alejandro; Pérez, María; Grimán, Anna C. (2006). Critical success ors for customer relationship management strategy. Information and Cusware holosy.

[22 Ng E.W.T. A Xiu \& Chau, D.C.K. (2009). Application of data mining techniques elationship management: A literature review and classification. Expert stems with Applications, 36 (2), 2592-2602.

[23] Pe d, Joe. (2000). Customer Relationship Management (CRM) in the Financial Serzices. European Management Journal, 18 (3), 312-327.

[24] Pfeifer, P.E., Haskins, M.E. \& Conroy, R.M. (2005). Customer lifetime value, customer profitability and the treatment of acquisition spending. Journal of Managerial Issues, 17(1).

[25] Safari, M. (2015). A conceptual model to explain strategic alignment in the financial services based on Balanced Scorecard. International Letters of Social and Humanistic Sciences, 2 (2), 98-108. 
[26] Safari, M. (2015). Customer Lifetime Value to managing marketing strategies in the financial services. International Letters of Social and Humanistic Sciences, 1 (2), 164173.

[27] Safari-Kahreh, M. \& Safari-Kahreh, Z. (2012). An Empirical Analysis to Design Enhanced Customer Lifetime Value Based on Customer Loyalty: Evidences from Iranian Banking Sector. Iranian Journal of Management Studies, 5 (2), 145-167.

[28] Safari-Kahreh, M.; Ahmadi, H. \& Hashemi, A. (2011). Achieving competitive advantage through empowering employees: An empirical study. Far East Journal of Psychology and Business, 3 (3), 26-37.

[29] Safari-Kahreh, M.; Tive, M.; Babania, A. \& Hesan, M. (2014). Analyzin the Applications of Customer Lifetime Value (CLV) based on Benefit Segat ation for the Banking Sector. Procedia-Social and Behavioral Sciences, 109 90-5)

[30] Safari-Kahreh, Z.; Shirmohammadi, A. \& Safari-Kahreh, M. (2012). emp. study to analyze customer relationship management strategy bal anod co ecard. Management Science Letters, 2 (5), 1603-1612.

[31] Seyed-Javadin, S. R.; Raei, R.; Iravani, M. J. \& Safari analysis to identify and prioritize the challenges of I amio nking im prementation: the case of IR Iran. International Letters of Social Huma ic Sciences, 24, 4555.

[32] Seyed-Javadin, S. R.; Raei, R.; Iravani, M. J. Safari, M. (2014). Presenting a conceptual model to explain the role of strate managem ent and planning in Islamic banking competitiveness. International Letters cacial and Humanistic Sciences, 26, 46-56.

[33] Seyed-Javadin, S. R.; Raei, R.; Iravan M. Pari, M. (2014). Presentation a conceptual model to explain determina of breakthrough the Islamic banking marketing: a managerial $\mathrm{p}_{\mathrm{p}}$ ive. Int national Letters of Social and Humanistic Sciences, 28, 58-66.

[34] Seyed-Javadin, S. B ac M. J. \& Safari, M. (2014). Conceptualizing and Examining th Critical s ess Factors for Implementing Islamic Banking System towards Bank $\mathrm{g}$. tor of Iran Mixed Method Approach. Iranian Journal of Managemen udies, ticle in press; available at: http://ijms.ut.ac.ir.

[35] Venkate san, R., Kumar, \& Bohling, T. (2007). Optimal customer relationship mana ment ag Bayesian decision theory: An application for customer selection. Journa larketi Research, 44(4), 579-594.

[36] oef, H \& Donkers, B. (2001). Predicting customer potential value an app cation in e insurance industry. Decision Support Systems, 32(2), 189-199.

[37] O-Fan; Hong, Wei-Kuo. (2006). Managing customer profitability in a petitive market by continuous data mining. Industrial Marketing Management, 35 : 71. 23 .

[38] Zeithaml, V. A, Rust, R.T. \& Lemon, K. N. (2001). The customer pyramid: Creating and serving profitable customers. California Management Review, 42(4), 118-142. 